\title{
Politics and the Academic Social Scientist; The Record of Talcott Parsons
}

\author{
Victor Lidz ${ }^{1}$
}

Accepted: 2 February 2021 / Published online: 15 March 2021

(C) The Author(s) 2021

\begin{abstract}
The decline of interest among sociologists in the works of Talcott Parsons over the last several decades has been driven in substantial respects by a belief that he was personally conservative in his political views and that his theoretical formulations were rigidly tied to a conservative view of social order. The present paper reviews Parsons' major political involvements through the course of his career from his student days through the last decade of his life. The review demonstrates that Parsons was a typical academic liberal of his time and that his liberalism was expressed especially in several major applied essays. In the 1930s, he was an early and active opponent of Nazism. During World War II, he taught professionals to administer occupied territories and nations effectively. After the war, he advocated for government support of the social sciences, citing the important contributions they had made to the war effort. In the 1950s, he wrote a famous critical analysis of the Joseph McCarthy movement in American politics. In the 1960s, he contributed supportive essays to the Civil Rights movement. Later in the decade and in the 1970s, he contributed to the protection of academic freedoms while also proposing accommodations to the demands of the student movement for more "relevant" teaching and greater participation in university governance. Throughout his career, he taught and worked closely with students of various political views and sought to protect their rights of freedom of political expression.
\end{abstract}

Keywords Value-freedom · Value-relevance · Civil rights · Academic freedom · Race relations $\cdot$ Social strain

Few aspects of Talcott Parsons' life and work have been as controversial in the profession of sociology as his applied social thought and his political views. Critics

Victor Lidz

lidzvic@gmail.com

1 Department of Psychiatry, Drexel University College of Medicine, 31 Independence Court, Chesterbrook, Philadelphia, PA 19087, USA 
of various points of view have attributed nearly every manner of opinion and outlook to him. He has been portrayed as rigidly conservative, as mildly and thoughtfully conservative, as an apologist for capitalism, as a liberal, as a social activist, and even, in the Joseph McCarthyist years of the 1950s, as a left-wing sympathizer of socialism or even communism. The latter view had sufficient consequence that a renewal of his passport was denied for a time in 1954. As Parsons himself often commented after noting contradictions among ideas attributed to him, not all these respected authorities can be correct. In this essay, I reexamine Parsons' social and political values, responses, and commitments with special attention to his efforts to affect public policy through applied writings.

\section{My Relation to Parsons}

Let me preface my discussion by emulating Mark Gould's essay in this issue and recounting some of my personal relationship with Parsons. Before I knew him, as a sophomore in Harvard College and resident of Adams House, I had a number of political discussions in the dining room with a senior, Daniel Frost. Once I asked Dan why he spoke in such odd terminology. He replied that he had been taking courses with the sociologist Talcott Parsons, who had developed a special technical terminology. He said the terminology facilitated more precise thought and communication about society and politics. He added that I might appreciate and learn a lot from Parsons' courses.

The next morning I was awakened at $8: 30$ by a knock on the door. It was Dan, who carried a handful of papers. He sat down on my bed and proceeded to show me reading lists from Parsons' courses: Comparative Institutional Analysis, American Society, Introduction to the General Theory of Action, and, perhaps, Sociology of Religion. He said that if I took one course I would read a lot of Durkheim, a name I did not know, and in another course a lot of Weber. He assured me that I would learn things no one in the Department of Government, my field of concentration, was teaching. After twenty minutes, Dan left and took the syllabi.

That summer, Dan, who was to start graduate studies with Parsons in the fall, drowned in a boating accident in the Charles River. Hearing that news when I returned to Cambridge, I took a course with Parsons, at least partly in respect for Dan's memory. Parsons was teaching Introduction to the General Theory of Action. The first lecture was fascinating. It discussed questions of scientific methodology and the importance of abstract frames of reference and analytical theory in bodies of social scientific knowledge. Parsons quoted "An Approximate Definition of Fact" (Henderson 1932) and Science and the Modern World (Whitehead 1925). I later understood that these materials had been at the foundation of action theory since The Structure of Social Action (Parsons 1937). At the time, I was impressed that Parsons sought to develop theory with logical consistency from a solid grounding. But I was also overwhelmed, as I had not encountered similar ideas before. Although I spent at least half of my time in the semester reading for the course, usually suggested as well as assigned readings, especially the then-translated essays on methodology by Weber (Weber 1949), I could not grasp it all. After the semester, I asked my father, a Professor of Psychiatry at Yale who knew Parsons' writings on the family, whether I should continue studying with 
Parsons. I felt that I had learned more from his course than any other I had taken, yet had received a grade of $\mathrm{C}+$. My father encouragingly replied that I should be guided by my interests and by what I was learning, not by one grade.

The next semester I took Comparative Institutional Analysis and the following year, American Society, which Parsons taught with his protege, Winston White, who proved to be an excellent teacher. White said that he taught "Parsons for the Idiot" and seemed always glad to interrupt his writing (cf. White 1961) to respond to a knock on his office door and answer questions about action theory. I spent the summer between my junior and senior years in Cambridge taking C. J. Friedrich's seminar on Totalitarian Government, but also reading or rereading some of Parsons' works, especially The Social System (Parsons 1951). That August, Parsons' gave a public lecture for summer school students on the sociology of knowledge. It was based on a paper he had recently given at an international meeting and later published (Parsons 1959). The elegance of its argument, especially its critique of Karl Mannheim, made a strong impression on me. I gave up my plan of attending law school to become a civil liberties lawyer; I planned to become a sociologist, that is, an action theorist.

I completed my concentration in Government, but took additional courses in Social Relations, including Erik Erikson's lecture course on the Life Cycle, a seminar on Chinese Society with Robert Bellah and John Pelzel, and the introductory course in Social Relations for all of the department's first year graduate students, as I had not taken the introductory course for undergraduates. I talked frequently about sociology with Ezra Vogel, whom I had met when he was in the Department of Psychiatry at Yale and had just arrived in the Social Relations Department. I applied to graduate schools and was accepted to the Sociology program in Social Relations.

Entering graduate school in the fall, I took Parsons' seminar on Topics in Sociological Theory, which focused on the generalized symbolic media of interchange (cf. Parsons 1963a, b, 1969). In the spring semester, the focus of my studies was on what we called "The Grand Seminar", the course that Parsons taught with Robert Bellah and Shmuel Eisenstadt, and in which the lectures of Bellah and later Parsons, despite Eisenstadt's learned skepticism, sketched out sequences of institutional changes in the subsystems of society that they called stages of social evolution, about which they later published. I attempted in my presentation to outline evolutionary changes in the political subsystem, although, aware of its weaknesses, I declined an invitation to publish my paper a couple years later.

At the end of that year, Parsons asked me to be his research assistant. Just what that would entail was unclear. Parsons rarely gave specific assignments. I gradually gathered that, if I read a manuscript he was writing and gave him critical comments on it, usually based on additional reading that I hastened to do, completed references, and attempted some editing of the text before his secretary typed up the final version, he seemed pleased. If my critical comments were at all extensive and seemed of interest to him, he sometimes asked me to "put it in writing". I would then write up a memorandum, which we would later discuss.

In the summer of 1963, he had already drafted some chapters of what was to become Societies; Evolutionary and Comparative Perspectives (Parsons 1966) and The System of Modern Societies (Parsons 1971). I began to read up on ancient Egyptian, Mesopotamian, and Mayan societies, thinking that his treatment of 'archaic' societies lacked empirical detail. I then wrote a memorandum about the differences between Egyptian 
and Mesopotamian societies, suggesting that Egyptian social structures emphasized the pattern maintenance and political functions, while Mesopotamian societies stressed economic and integrative functions. Parsons asked that I lend him some of the books I had read. He then initiated several sessions in which we discussed Henri Frankfort's Kingship and the Gods (Frankfort 1948) in detail. He filled his office blackboard with diagrams of themes in Egyptian mythology and their relations to the institution of the pharoah and royal household. He then rewrote the chapter on archaic societies, adding a lot of new detail and contrasting Egyptian and Mesopotamian institutional patterns as my memo had proposed. I felt that indirectly I had made a contribution to sociology!

I continued as Parsons' research assistant until the summer of 1968, when I left to become an Instructor at the University of Chicago. ${ }^{1}$ During my years as his assistant, that work became the core of my education. I read a great desal on many topics as part of what I assumed were my duties. During our afternoon discussions, Parsons allowed me to raise questions about almost any topic, any of his own writings, or almost any work I was reading related to action theory. The discussions typically occurred once or twice per week and ranged over an hour or two. For Parsons, having a research assistant was continuous with his teaching (cf. Fox 1997).

From the fall of 1964 through the spring of 1968, I was also resident tutor in Kirkland House, teaching sophomore group tutorials in Social Relations, occasional individual tutorials for juniors and thesis supervision for seniors. A few students in one of my sophomore groups took a course with Parsons in their junior year. After the first lecture, they insisted that I join their table at dinner in the house dining hall. When I sat down, they said in unison, "Did you ever brainwash us."

While I was at Chicago, the department chair, Morris Janowitz, arranged that Parsons teach for one semester in each of two academic years. When Janowitz reached a firm agreement with Parsons over the phone, he called me and directed me to meet with him immediately. The core of what he then said was that he had just learned Parsons' Harvard salary. He wanted me to know how badly Harvard treated the professor I so admired. Janowitz made clear that he would not work for such pay! When Parsons visited Chicago, it was with a joint appointment in Sociology and Anthropology. Both times, I taught a seminar with him - once on the general theory of action and once on the generalized symbolic media of interchange - while David Schneider taught a seminar in Anthropology with him.

After I moved to the University of Pennsylvania, Renee Fox arranged that Parsons would come to the university as part-time visiting professor for one semester for each of several years. Each year, Renee and Willy DeCraemer taught a course with Parsons while Harold Bershady and I taught another with him. Typically Parsons came for one or two weeks per month, while the others of us kept the courses going in his absence. Harold and I taught American Society to undergraduates and General Action Theory to graduate students, while Renee and Willy taught Sociology of Medicine and, I think, Sociology of Religion. During the weeks that Parsons was in town, a small group of us also held an informal faculty seminar to discuss a memorandum Parsons had written on

\footnotetext{
${ }^{1}$ Parsons had perceived that in the 1967-68 academic year, I was spending time during vacations and long weekends in Chicago, visiting the woman who became, and is, my wife, who had started graduate school there. Without first speaking with me about it, he kindly arranged through Peter Blau, to the extent that collegial relations could accomplish it, that I be offered the position.
} 
the human condition. A. Hunter Dupree from Brown University, Robert Bellah, and Clifford Geertz also met with the seminar. The long essay that resulted from the seminar discussions became Parsons' last major contribution to sociological theory (Parsons 1978).

The years of my association with Parsons were ones of rapid development in the theory of action. The four-function analysis of societal subsystems was consolidated, the treatment of 'generalized symbolic media' was refined, the evolutionary theory and scheme of stages of societal development was advanced, the 'theory of general action' (the relations among culture, social systems, personality, and mind; Parsons 1970) was reformulated, and the human condition paradigm was proposed. The same years were also a time in which three related developments affected the reception of Parsons' work. First, most sociologists did not keep up with the radical changes in his theory. Many believed, having read The Social System, they knew the basics of his work and could evaluate it effectively. Second, many social scientists came to believe that Parsons was a hidebound conservative out of step with the left-leaning politics increasingly predominant in academia. Third, many, likely most, sociologists came to believe his system theory and concerns for explaining social order were tied to his supposedly conservative outlook, hence that they could simply dismiss his writings. His theory came to be viewed as part of the conservative 1950s and the privileged position of a Harvard professor.

Everybody schooled in Parsons' works knows these conclusions to be wrong, yet they persist. In the following discussion, I review his actual liberal, left-Democratic political views and commitments. My goal is to clarify his social and political outlook, Weltanshauung, or 'ideology', with a focus on his understanding of his social role as an academic social scientist, including several occasions on which he tried to influence American politics. My interpretation is based primarily on his published writings, methodological, theoretical, and applied. I will also draw on some unpublished writings in the Harvard University Archives and on statements he made in my presence during the nineteen years that I was his student, assistant, research collaborator, and coinstructor.

\section{Personal Background and Education}

Certain dimensions of Parsons' Weltanschauung, personal identity, and understanding of his social role derived from his family upbringing (C. Parsons 2004). His parents maintained the ascetic Protestant culture associated with their New England Congregationalist heritage. They emphasized a disciplined, hard-working, intellectual, and personally modest manner. This conservatism in personal manner was combined with the strong interest of Parson's father, who was trained as a minister, in the Social Gospel movement. The mature Talcott Parsons was proud of a family connection to the eighteenth century theologian, Jonathan Edwards, and his father's copy of Calvin's Institutes held a prominent place in his office bookcases. Yet, his religious beliefs, about which I never heard him talk, were apparently more liberal. ${ }^{2} \mathrm{He}$ adhered to a

\footnotetext{
${ }^{2}$ He once told me in a joking manner that since Helen's family had been Episcopalian and his Congregational, they had "compromised" by raising their children in the Unitarian Church. He did not say what sort of belief or practice the family may have shared.
} 
conservative modesty in personal manners that I perceived as a modernized Puritanism. He eschewed the teetotalling rule of his parents, although Helen Parsons once told me that she and Talcott had never presumed to drink alcohol in his parents' presence. He expected hard, steady, and highly productive work of himself. On a routine day, he spent three to four hours writing in the morning; devoted the afternoon to teaching, meeting with students and colleagues, committee work, and correspondence; and after dinner returned for a few hours to reading, dictating letters, and professional work - or, if pressed to finish an essay or anxious to work up a new idea, to writing. His commitment to steady work impressed me when I found that, after returning from vacations, he sometimes apologized to me: he had been writing for only a few hours a day.

Parsons' personal modesty was also apparent in his correct but plain style of life. He generally wore moderately priced, often old academic tweeds, and he tended to keep shirts and jackets in service despite burn holes from ashes of his cigarettes. On formal occasions, he wore a classic blue pin-striped suit, possibly the same suit all the years I knew him, and plain black shoes, old enough for the leather to be cracked. His home was comfortable but unpretentious, with decoration, furniture, and some appliances apparently little changed since the late 1930s. He customarily drove the least expensive car he could purchase new. He once commented to me that he resisted buying such "extras" as an automatic transmission, then asked if I thought it extravagant that his new car had a radio. ${ }^{3}$ He tended to be reserved, even shy, in relations with students and colleagues, but always proper. With students and colleagues whom he knew well, he was generous with his time. I was often surprised at the length of time he would take to discuss a sociological issue with me, and his care to be thorough in responding to questions.

Parsons' liberal outlook was evident as early as his undergraduate days at Amherst College. The attraction to social science that displaced his earlier goal of studying biology in preparation for a medical career was bound up with the liberal 'institutional school' of economics that predominated at Amherst. Parsons also studied Sumner, but it was reading Veblen and Commons that attracted him to economics and social science. At Amherst, Parsons developed a special concern for academic freedom of study and expression. When the Amherst president, Alexander Meiklejohn, was removed by the trustees under circumstances suggesting his outspoken liberalism had earned their distrust, Parsons was among the small group of students who expressed public opposition to the trustees' decision and admiration for Meiklejohn's academic leadership (Parsons and Cutler 1923). Parsons later spoke of his views when completing college as sympathetic to democratic socialism in the Anglo-American, nonMarxist mold.

After graduating from Amherst, Parsons matriculated at the London School of Economics. For a student with an interest in economics and his political sympathies, the L.S.E. was perhaps the world's leading academic center. Parsons enrolled with high expectations, but during the year was mostly disappointed. He later remembered only

\footnotetext{
${ }^{3}$ The time and setting of his comment and question are memorable. We were driving into the parking lot of The American Academy of Arts and Sciences, of which he was then president, for a conference he had organized on the relations between biological and social scientific theory. His new car, an American Motors Javelin, was literally the cheapest car on the American market. All the other cars in the parking lot were Mercedes, Volvos, and Buicks.
} 
Malinowski's course in anthropology as inspiring. Hobhouse and Ginsberg's teaching in sociology he found analytically thin and empirically shallow, if encyclopedic. Tawney's teaching was limited due to illness that year, but Parsons apparently found the descriptive quality of his economic history helpful, although not inspiring. Harold Laski made a better impression and Parsons later kept in contact with him.

For the next academic year, Otto Manthey-Zorn, the Amherst philosophy professor of German and philosophy, arranged a scholarship for Parsons to study at a German university. The scholarship program assigned him to the University of Heidelberg, apparently through the influence of Carl J. Friedrich, later in Harvard's Government Department and a friend. At Heidelberg, Parsons encountered the influences that were to become the chief source of his thought about the social role of the social scientist in the corpus of Max Weber's writings. Soon after arriving in Heidelberg, Parsons began study of The Protestant Ethic and the Spirit of Capitalism (Weber, 1903-04/1920a), which made a special impression on him due to his Calvinist family background. He then studied the corpus of Weber's comparative studies (Weber, $1920[1952,1958]$ ) as well as Weber's general concepts and methodology. His studies of Weber were deepened by Jasper's seminar on Kant and reading in Neo-Kantians, such as, Windelband, Rickert, and Troeltsch.

\section{Methodological Background}

From his Heidelberg studies, Parsons gained familiarity with the concepts of Wertfreiheit (value-freedom) and Wertbeziehung (value-relevance), as counterbalanced in Weber's methodology (cf. Weber 1949). In Weber's view, the production of knowledge involves meeting the standards of a "schema of proof" in order to approach objectivity and thus intellectually disciplined freedom of the resulting findings from specific practical or ideological values. The schema of proof involves matters of logic and handling of empirical evidence. Works that approach objectivity - no empirical work can rise above the limitations of knowledge at a given time fully to attain objectivity have scholarly value across a range of value-laden outlooks or Weltanschauungen. Yet, all efforts to produce knowledge are embedded in the socio-cultural settings of their creation, including the values and interests of investigators. Knowledge cannot be "immaculately conceived", Parsons used to say. The scholar has practical values that shape his or her interest in empirical matters to investigate as well as the particular aspects of phenomena he or she is able to perceive and formulate. These values and interests are always discernible in a completed study; created knowledge always reflects the social and cultural circumstances of its creation.

In Weber's methodology, value-freedom and value-relevance are both irreducible aspects of well-formed contributions to knowledge. They are in tension with one another, and it is a methodological error to reduce either dimension to the other. The apparent value-relevance of a study - that it was undertaken to advance 'capitalist' or 'socialist' goals or to promote individual liberties or to strengthen institutions of authority - does not intrinsically detract from its possible objectivity. Its objectivity must be evaluated in terms of the degree to which it adheres to the schemas of proof appropriate to its intellectual discipline. Yet, a contribution to knowledge, while it may be 'scientific' or objective, also constitutes a social or political act. The scholar must 
justify his or her investigation in terms of the social, political, or ideological values that underlie decisions about its value-relevance. That is, the scientist or scholar must take responsibility in terms of practical values for such acts as well as academic standards.

This perspective remained constant in Parsons' methodological views; it did not change as elements of his general theory evolved. He wrote about the irreducible relationships between value-relevance and value-freedom (and schemas of proof) in similar terms throughout his career: in his review of von Schelting's Max Weber's Wissenschaftslehre, The Structure of Social Action (1937), Social Science; A Basic National Resource (1948), "An Approach to the Sociology of Knowledge" (1959), his paper for the Heidelberg Weber Centennial Conference, "Evaluation and Objectivity in the Social Sciences: An Interpretation of Max Weber's Contributions" (1964), "A Paradigm of the Human Condition" (1978), and "The Sociology of Knowledge and the History of Ideas" (circa 1977/2006).

Parsons knew some of Weber's commentaries on events in German politics published in the Frankfurter Allgemeiner and elsewhere. He also knew of the active role that Weber assumed in German public affairs, the ethically scrupulous ways in which he justified that role, and his ambitions to have played a greater role near the end of his life. From the biography by Marianne Weber (1926/1975), from attendance at the famous Sunday afternoon teas she continued after her husband's death, from discussion with Alfred Weber and Else Jaffe, and from the 'legends' of Weber in Heidelberg, he knew about the socially engaged aspects of Weber's work. He also knew the great Munich lectures on Politik (Weber 1919a) and Wissenschaft Weber 1919b) as Vocations. They were part of the role model he found in Weber, although he would never have adopted the prophetic tone of Weber's Munich lectures. (He was critical in the late 1960s of what he called Robert Bellah's "prophetic" manner in The Broken Covenant (Bellah 1975), even though Bellah was the former student and colleague for whom he held the highest regard and expectations.)

In Parsons' self-understanding, he was unsuited to a public role in politics. He never took on a role remotely like Weber's consultation with the German delegation to the Versailles Treaty negotiations or the public role Weber was preparing to play in the period before his death (cf. Radkau 2009). Parsons' personal identity was fully tied to academic roles, although he held, and voiced, political and social views on many matters he believed important. Any role he might adopt in public life would have to be integrated with his academic vocation. Writing sociological analyses of public problems was an aspect of Weber's model that, on important issues, Parsons could embrace. From early in his career, he contributed his sociological understanding of political events to public discourse, focusing on matters of special value-relevance to himself.

Parenthetically, Parsons showed little to no interest in engaging in economic activities beyond earning his professional salary, as they would have distracted him from academic work. I do not recall his ever talking about investments beyond praising T.I.A.A. for providing financial security for retired academics. When examining papers in his study after his death, I found many old checks stashed in the middle drawer of his desk: he had simply not bothered to cash checks received as honoraria for public lectures.

Parsons' qualifications for his first academic positions, in Departments of Economics at Amherst and Harvard, consisted mainly of his training in German historical and social economics. His first articles, English reworkings of the dissertation he had 
written in Gerrman (Parsons 1927/2019a, 1927/2019b), dealt with the conceptual schemes of major contributors to that school, principally Sombart and Weber (Parsons 1928, 1929). Not until his review article on von Schelting (Parsons 1936) and The Structure of Social Action (Parsons 1937) did he address the deeper methodological foundations. The discussion of Weber's methodology is one of the richest sections of Structure.... It makes clear that the neo-Kantian concerns and Weber's formulations in methodology continued to define central issues for his own contributions.

Elsewhere I have emphasized, as have Enno Schwanenberg (1976), Jan Loubser (1976), Thomas Fararo (1976), and, in greater detail, Harald Wenzel (1990), that the methodology presented in Structure rests more on Whitehead's (1925) analytical realism than on neo-Kantianism. This interpretation follows Parsons' own accounts of the development of his analytical theory. in his writing, his teaching, and personal discussions. In his accounts, the synthesis of Structure and later works was made possible by adopting analytical realism with its emphasis on abstraction guided by an analytical conceptual scheme or frame of reference. Yet, throughout his career, Parsons continued to think through many issues in terms of the Weberian concepts of Wertbeziehung and Wertfreiheit supported by schemas of proof and standards of objectivity. Following Weber, Parsons held that every authentic contribution to knowledge consists of elements shaped by historically relative factors, such as judgments about what phenomena are worthy of study, and factors that strive for universal validity in terms of a "schema of proof."

Schemas of proof differ by field, e.g., physics, biology, social science, history, and by epoch in the development of a field. Parsons knew of the importance of this from reading Whiethead's Science and the Modern World (Whitehead 1925), which emphasized how modes of abstraction and frames of reference grounding methods of proof have evolved in the history of the sciences. In physics, Newtonian mechanics, the theory of relativity, and quantum theories involve different schemas of proof. In biology, Darwin's emphasis on natural selection introduced a new schema of proof, later supplemented by Mendel and still later by the Watson-Crick double helix model of DNA. Parsons' ambition in Structure was to revolutionize the modes of abstraction and frames of reference for social science by establishing a universal schema of social action. Later formulations, such as the social system, the pattern variables, and the fourfunction paradigm, were also intended to establish constant theoretical elements for schemas of proof. Many elements of schemas of proof are tied to well-defined procedures or techniques for gathering and analyzing specific ranges of empirical evidence, for example., x-ray crystallography. Statistical methods, such as t-tests, analysis of covariance, regression models, and so forth contribute to schemas of proof across a range of disciplines. Knowledge formulated rigorously in terms of an appropriate schema of proof may sufficiently approach objectivity that it need not expire with the notions of value-relevance that motivated its creation; it may have enduring significance, even validity.

Over time, disciplines evolve more demanding schemas of proof. They then impose stricter criteria for assessing degrees of success and failure regarding claims to the validity of particular contributions to knowledge. We see such historical processes at work even for such great scholarship as Weber's comparative studies of religious ethics and civilizations (Weber 1920a, b, c, d). They were motivated by the value-relevant goal of understanding the modern capitalism of the West and its complicated interdependence 
with inner-worldly asceticism, rationalistic law, science, formally organized bureaucracy, and bourgeois dominated class and status systems through broad comparisons with the institutional complexes of other civilizations (Weber 1922/1968). With his ambivalent, foreboding outlook on capitalism, Weber was hardly an apologist for modernity or Western civilization. He achieved a remarkable degree of objectivity through verstehende analysis of several major civilizations and the use of ideal types and a scheme of general categories. Today, however, the value-relevance of his studies has been altered by many changes in the capitalist social order that now extends to civilizations outside the West. The ideal types he used to analyze classical antiquity and historical Indian, Chinese, and Muslim societies now appear less persuasive than decades ago. The barriers to modernity and capitalism he identified with his ideal types for these civilizations are no longer present in the same ways. Nevertheless, contemporary sociology finds an important precipitate of objectively valid knowledge in Weber's studies.

In affirming the possibility of permanently and universally valid knowledge in studies such as Weber's, Parsons constrasted the Weberian methodology with the 'sociology of knowledge' perspective of Mannheim (1929/1936), which views all knowledge as limited in significance to particular configurations of cultural, social class, political, or economic interests (Parsons 1959). Like Weber, Parsons understood that "the selection of the material of science" may rest on values and interests of many kinds, but "once this material is given it is possible to come to objectively valid conclusions about the causes and consequences of phenomena free of value judgments and hence binding on anyone who wishes to attain truth, regardless of what other subjective values he may hold" (Structure, p. 594).

Parsons' primary goal throughout his career was in developing intellectually disciplined means of reaching, to repeat, "objectively valued conclusions about the causes and consequences of phenomena free of value judgment." Despite his fame for prolix prose, there is no more succinct way of stating this goal. Note that Parsons anticipates that properly disciplined knowledge is binding on any seeker of truth, whatever his or her non-scientific values or interests. Seekers of truth may differ in other values, as Parsons believed inherent to scholarship in highly differentiated and diverse socieies. At every stage of his career, he worked with students and collaborators whose political views were to the right (Marion Levy, Edward Laumann, Charles Ackerman) or to the left (Robert Bellah, Jesse Pitts, Mark Gould) of his own. The collaborations focused on a shared search for truth and objective knowledge.

In Parsons' usage, to speak of a work as value-free is to characterize its approach to the ideal of objectivity, but not to claim that it was created without specific value-relevance. Over the years, the term value-free, as applied to commitments to achieving objectivity, has led to much misunderstanding. We should not think that Parsons ever believed his or any other sociologist's research or teaching to have been created free of connection to social or political values or of conditions and interests particular to times, places, and historical conditions. As noted, he did not believe in "immaculate conceptions" of knowledge.

\section{The Value-Relevance of Major Writings on Policy Issues}

With this methodological background, I will review several major policy areas on which Parsons wrote politically significant works. He also engaged in one confidential 
attempt to affect American national policy. Each of these matters concerned an issue on which he held strong views, focused his analytical abilities, and became politically active.

As Uta Gerhardt (1993) has fully documented, Parsons was an early and outspoken American opponent of Nazism. In the mid-1930s, he became a leader among Harvard faculty members who sought to mobilize public opinion against Nazism and the American Bund. He was outspoken in opposing Nazi violations of academic freedom in the German universities and Nazi attacks on elements of German high culture. He became active in opposing German militarism and expansionism. In 1939, he was an early proponent of support for Great Britain and preparing the U.S. for war. During the pre-war period, he published articles in the public press and spoke on a Boston radio station as well as engaging in a high level of activity in the university, speaking before student and faculty groups.

Parsons' political statements were not anti-German, but anti-Nazi, even during and after the war. He continued to show his respect for German culture and its place in Western civilization - the Germany of Kant, the Neo-Kantian movement, and Max Weber so important in his education, but also the Germany of Bach and Beethoven, Goethe and Schiller, the nineteenth century research university, the foundations of modern historiography, nineteenth century chemistry, and twentieth century physics. During the post-War years, when it was common in American social science to stigmatize Hegelian philosophy and social thought as mystical and intrinsically susceptible to regressive romanticism and totalitarian ideas, Parsons refrained from such overly simple criticism. His opposition to Nazism was rooted in a positive appreciation of German high culture and awareness of the value of protecting that culture.

In the late 1930s and early 1940s, Parsons wrote influential essays that sought to explain the rise of Nazism in Germany (Gerhardt 1993, which includes Parsons 1940, 1942a, b, c). His analysis focused on the speed of industrialization in Germany from the mid-nineteenth century down to the Great Depression, the many social strains generated by fast-paced industrialization, the comparatively late and fragile political unification of the nation, the particularly bitter conflicts in the German class and status structure, and the tensions between the universalistic pressures of the modern Gesellschaft and the remaining elements of small-state localism and Gemeinschaft romanticism. In later years, he also emphasized the adaptations that had evolved between the activistic Calvinism of the Hohenzollerns and other dominant strata in Prussia and an inward-turning, mystical, and passive manner of the Lutheran middle classes in most of Germany (Parsons 1971). Parsons also emphasized a relation between strains in German social structure and a projection of hostility toward vulnerable groups defined as outsiders, as not authentically German, or as traitors, especially Jews, other ethnic minorities, communists or socialists, and people with disabilities.

As Gerhardt (2002) has documented, Parsons used his professional influence in an effort to defeat the 'Morgenthau Plan' debated in the Roosevelt administration late in the war. This plan was to deindustrialize Germany, returning it to an agricultural economy, to ensure that it would never again possess the resources to wage war. The plan would have impoverished the German population and left it dependent on other nations for necessities of modern life. Parsons feared the Morgenthau Plan would also destroy Germany's capacity to renew its high culture with institutional bases in free universities and civic institutions. He thought it would generate a nationalistic backlash 
like the one created by the Versailles Treaty, perhaps even more severe. In opposing the Morgenthau Plan, Parsons' activity did not involve publication and appeals, but letters and memoranda sent to Harvard colleagues influential in Washington.

In the post-war period, Parsons published a notable essay on the socio-cultural sources of aggression in the Wesrern world (Parsons 1946). The essay argued that factors fostering aggression against 'outside' and marginal social groups and foreign states deemed enemies had powerful sources in the inner-wordly activism of the West, very much including American society. At a time when other social scientists, perhaps especially psychoanalysts, saw such aggressive tendencies as deeply rooted in German culture, Parsons identified broadly similar tendencies in the U.S. and other Western societies. In retrospect, the essay appears as a warning against both some of the domestic conflicts of the decades since and the excesses in international affairs that emerged during the Cold War, including the Vietnam War, perhaps extending to the wars in Iraq and Afghanistan.

Parsons again became publicly active during the 'McCarthy Era' of political and legal suppression of the 'left' in the 1950s. Parsons supported the free exercise of civil liberties without limitation due to citizens' political outlooks or affiliations. He discerned early on that universities and members of their faculties associated with the political left would become targets of Senator McCarthy and others in Congress and in the public press. He became active in the Harvard chapter of the American Association of University Professors (Nielsen unpublished), joined public petitions defending the civil liberties of academics under investigation or attack, and wrote letters to the press. A leader of the Harvard AAUP in the mid-fifties, he defended members of the faculty whose continuing appointments were threatened by political pressures both outside and inside the university. He emphasized the First Amendment rights of citizens and the still broader needs for freedom of communication in academic settings. He argued that all faculty and students should be accorded full rights of free speech and publication. He emphasized that faculty appointments should be based on professional and intellectual qualification, not political tests. He also served for a time as faculty advisor to the John Reed Society, a student group sympathetic to socialism and communism, which under Harvard rules could not otherwise have remained a student organization. He did so despite disagreeing with the society's politics in order to protect the rights of student members to associate and publicize their views. In the years I knew him, Parsons expressed views close to absolute on First Amendment rights, especially within academia.

In 1953, as Visiting Professor at the University of Cambridge, Parsons found that many British intellectuals believed that Joseph McCarthy was emerging as an 'American Hitler' and talked of preparing for the U.S.'s decline into fascism. In response, Parsons wrote the essay "McCarthyism and American Social Tension: A Sociologist's View", better known by the title under which it was reprinted, "Social Strains in America" (Parsons 1955). The essay argued that McCarthyism was a limited political movement without serious prospects of gaining control of the nation's leadership. It is likely that his own difficulty in renewing his passport in order to travel to England played a part in his decision to write the essay, as did the subjection of his colleague, Samuel A. Stouffer, to a serious loyalty investigation during the same academic year. Parsons was confident of his own national loyalty and knew that investigation of his personal political commitments was unwarranted. He also knew that Stouffer, a 
Republican, was a political conservative who was extremely proud of his wartime service as principal author of studies collected as The American Soldier (Stouffer and others 1949). Stouffer's academic reaction to McCarthyism was the empirical study published as Communism, Conformity, and Civil Liberties (Stouffer 1955), a work Parsons assigned in courses. In undertaking to write "Social Strains in America", Parsons perceived a need to contribute greater social scientific understanding to the defense of civic freedoms.

"Social Strains in America" argued that the social base for McCarthyism was largely in the population of small towns and among independent proprietors of small businesses. The base was in predominantly middle-class groups, but ones that had suffered comparative economic decline and loss of social status during the rise of large industry and big government over the previous generation. They saw trends in the larger society as threatening their ways of life, which they experienced in terms of reduced respect in the broader community as well as declining economic prospects. The resulting resentments toward social change left them susceptible to McCarthy's allegations that the ranks of government leaders included traitors, Communists and sympathizers of Communism, covertly making decisions that would weaken the nation. They tended to believe that national leadership had failed to protect valued ways of life during the Great Depression, World War II, and the Cold War.

A common belief among McCarthy's supporters was that American society at large had betrayed traditional values honored in their own ways of life. The strains of relative deprivation in practical circumstances and social status had generated a broad ideological discomfort with trends of national policy, hence a tendency to blame groups that had prospered through the same processes of social change. In lectures, Parsons noted that Secretary of State Dean Acheson, wealthy, well-educated, patrician in personal style, well-connected on Wall Street, in Ivy League universities, and in Washington, and a proponent of "internationalist" policies, became a central figure on whom distrust was projected. McCarthy and others alleged that Acheson protected disloyal "Communists" in the State Department, particularly favorites, such as Alger Hiss, who shared his class and educational background.

Parsons argued that the limited social base of McCarthy's supporters would prevent the movement from growing into a predominant political force. The many groups in society that had benefited from the social changes of the previous generation and become tied to a social order of large-scale industry and regulatory and welfare protections from government, would be unlikely to respond to McCarthyism. American society differed from Germany during the rise of Nazism in that a large majority of citizens were not susceptible to the bitter disaffection from national institutions that had occurred in the Weimar political system. The conflicts and jealousies among classes and status groups, though quite real, were more limited than in Germany in the 1930s. Parsons concluded that McCarthism was a 'bubble' phenomenon. It had expanded rapidly through strong appeal to a specific social base and appeared to threaten the political order. However, when challenged emphatically, McCarthyism would decline rapidly in the manner of previous 'populist' movements in American history. Parsons favored firm and deliberate opposition to McCarthy and his allies, but eschewed the tendency on the left to exaggerate their novelty and strength.

Like his essays on the development of Nazism in Germany, Parsons' essay on McCarthyism was not only a response to a political movement he opposed, but also an 
innovative contribution to political sociology. The early ' $50 \mathrm{~s}$ was a time when the concept of social strain was becoming increasingly prominent in efforts to understand causes and consequences of change. Parsons' essay was innovative in applying the concept of social strain to understanding contemporary American social movements and politics, especially relationships between strain and political ideology. Parsons' perception of the negative value-relevance of the McCarthy movement - an attack on American traditions of civil liberty - led him to advance sociological theory dealing with social change, strain, and the genesis of political ideologies and movements.

During the 1950s, Harvard University came under considerable political pressure to dismiss members of its faculty and student body affiliated with the Communist Party or political groups seen as associated with the Communist movement. Although the university emerged from this period of intense pressure with a reputation for leadership in protecting academic freedoms, newer research has revealed a mixed picture (Schrecker 1986). Some assistant professors failed to get reappointments for reasons that appear to have been more political than academic. At least one tenured faculty member found his duties changed and his role more peripheral to the university. Some graduate students, teaching assistants, and instructors found the progress of their professional careers obstructed by the administration. Among the latter was Robert Bellah, then Parsons' student. Parsons was vigorous in protecting Bellah's status as a graduate student when MacGeorge Bundy, then Dean of the Faculty of Arts and Sciences, threatened it. Later, uncertain of his threatened prospects for a faculty appointment, Bellah left Harvard for McGill University where he would be beyond the reach of American politics. Parsons told him that his leaving Harvard "was not the end" of the matter; he was instrumental in recruiting Bellah back to Harvard two years later (Bortolini forthcoming).

Parsons became politically active during the late ' 50 s and early ' 60 s on Cold War issues that were partly related to his position on McCarthyism. By 1958, Parsons came to believe that, due to the ideology of vigorous prosecution of the Cold War, American political leaders were taking unnecessary risks of a third world war. Early in the Cold War, Parsons had favored strong opposition to the Soviet Union. His participation in the establishment of the Russian Research Center at Harvard was based partly on the view that the Soviet Union constituted a ruthless, long-term adversary of the U.S. Better scholarship on the Soviet Union should help to engage that adversary more wisely and effectively. Parsons served for years on the faculty board of the Russian Research Center to help guide development of its scholarship. But a decade later he believed that intense engagement in the Cold War had blinded American policymakers to a basic reality, that the U.S. and U.S.S.R. shared an overriding interest in maintaining peace and avoiding nuclear war.

From that perspective, Parsons wrote a pair of papers on American foreign policy in relation to the system of international relations (Parsons 1961a, b). At the time, many scholars and nearly all political leaders maintained that the U.S. should pursue every possible advantage against the Soviet Union. Political rhetoric often suggested that civilization itself was at stake. Parsons acknowledged the differences between West and East, yet argued that the U.S. and Soviet Union shared interests in limiting conflict to prevent a 'hot war'. He proposed that U.S. foreign policy should work toward defining a mutually acceptable world order that would limit both powers in pursuing conflicting interests. He suggested that the differences between the cultures of the U.S. and Soviet 
Union were not completely unbridgeable, as both nations shared values of improving material conditions for their populations and appreciation of science and technology. He emphasized developing greater confidence in the international order, including trust between the U.S. and the Soviet Union. He favored trade and various personal, cultural, and scientific exchanges between the two nations. He was proposing a 'Durkheimian' strategy of developing normative constraints to limit the pursuit of national selfinterests, promote international solidarity, and build institutional protections against escalation of conflict.

Parsons' proposals were intended as suggestions for a practical shift in policy. He was not proposing a utopian alternative to American foreign policy. He hoped to broaden the American (and perhaps Soviet) understanding of national self-interest, so that securing conditions of peace would gain greater prominence in calculations of national interest. In the background was his belief that intense concentration on the Cold War was harmful to American domestic politics, as discussed in his "Social Strains" essay, as well as risking a catastrophe of nuclear war.

Some years later Parsons participated in the Pugwash Conferences, where scientists from both the U.S. and Soviet Union held discussions on shared control and destruction of nuclear weapons. In the mid-1960s, with the first thawing of the Cold War, Parsons made contacts with Soviet sociologists. He traveled to Moscow to meet and exchange ideas with Russian social scientists and encourage their participation in meetings of the International Sociological Association. At his invitation, Soviet, Hungarian, and Polish sociologists gave colloquia at Harvard in the late 1960s. Parsons was rewarded for these efforts by learning that Russian translations of chapters of The Social System had gained circulation among Soviet sociologists in Zamisdat (underground copies made through loopholes in the controls over copy machines, then circulated privately). He delighted in the idea that his 'bourgeois' writings had seemed so subversive that Soviet authorities had banned them.

During the late 1950s and early 1960s, the social sciences in the United States began to focus on problems of economic and social development in the so-called underdeveloped or third world countries. Most of the development literature was liberal in orientation, emphasizing the need for developing nations to create "free" market systems for their economies and democratic political systems supported by freedom of speech and association. Parsons participated in several conferences on the economic and political circumstances and prospects of developing nations. He included two essays based on presentations to such conferences in his collection, Structure and Process in Modern Societies (Parsons 1960), "Some Reflections on the Institutional Framework of Economic Development" and "Some Principal Characteristics of Industrial Societies". The two essays are complementary and emphasize similar points. In the background, we should note, Parsons had held as a central interest, at least since first reading Weber's Protestant Ethic... monograph, in understanding the unique pattern of social institutions that had developed in modern Western civilization. His starting point in analyzing the prospects for developing nations was that their trajectories of social change were likely to be quite different from that of Western civilization. In part because he was familiar with Robert Bellah's Tokugawa Japan, Clifford Geertz's studies of social change in Indonesia, and recent studies at Harvard's Russian Research Center on the inefficiencies of planned economies, he anticipated that courses of future development and the resulting institutional patterns would be shaped substantially by 
the prior cultural traditions of various nations and in some cases by their experiences under colonialism. Thus, Parsons was critical of analyses that presumed developing nations would prosper by simply following the course of American experience. ${ }^{4}$

Parsons' critiques of much of the development literature made several key points. Positive evaluations of the prosperity of Western societies was widespread, nearly universal, and thus global processes of social change were occurring and would be sustained. In the West, historical development was advanced by the autonomous entrepreneurship of independent actors and economic entities. Most non-Western societies lacked highly motivated independent entrepreneurs, but they did have political leaders committed to modernizing their economies. A common result was likely to be government-sponsored economic development and far less reliance on independent business firms and open market systems. Parsons emphasized that a set of legal institutions essential to modernization in the West, contract, property, and occupation (the norms regulating work in settings outside the home and under the supervision of a separate organization) were lacking or greatly underdeveloped in most nations. This fact, too, tended to complicate the course of social change in underdeveloped nations. Parsons did not present himself as pessimistic about the future of developing economies, but he underscored complications that were often being overlooked.

Developing nations also lacked, in most cases, the political traditions of democratic republics with emphasis on free speech, a free press, and freedom of assembly. Hence, it should not be anticipated that democratic institutions would readily emerge as the settings for economic prosperity. Nor should one anticipate that prosperous middle classes would emerge and provide political support for economic advancement. It was all-too-likely that economic growth would result in the crystallization of wealthy cliques that would dominate both economic and political institutions while large portions of the populations would remain impoverished.

Parsons agreed with the democratic and liberal ideals that were guiding most of the American literature on economic and political development, some of it disattending to the global political entanglements in which the country was becoming engaged, elements of which would end in the Vietnam War. Yet, Parsons' Weberian scholarship led him to emphasize a range of complicating factors that were being overlooked in the early literature. I would not suggest that he was injecting a deep pessimism into the picture, but he did have a comprehensive realism that was unusual before the late 1960s.

Another issue on which Parsons became politically and intellectually active concerned the Civil Rights Movement. With its growth in the late 1950s and the 1960s, Parsons became a sympathetic and firm supporter. Among friends and students, he expressed his admiration for the personal courage of the movement's leaders and supported a range of its organizations and their legal-civic and democratic aspirations. He was impressed especially by the Reverend Martin Luther King, Jr.'s eloquence and ability to tie the movement's appeals to fundamental American and Judeo-Christian

\footnotetext{
$\overline{4}$ In the mid-1960s, I attended a "going away" party for an assistant professor of economics at Harvard who was joining a Harvard team to advise the government of Pakistan on economic developed. I discussed with him the complex challenges that I, as a Weberian, anticipated he and his team would be confronting - a society that lacked a culture of "inner-worldly asceticism", Western-style institutions of property and contract, and a "bourgeois" middle class. He assured me that, with the advice of Harvard economists, these problems were easily overcome. Pakistan would have a fully modern, European-style economy in twenty years.
} 
values. At Harvard, he supported research on race relations and the admission of larger numbers of African American students to undergraduate and graduate programs. In the mid-sixties, active in the American Academy of Arts and Sciences, he helped to arrange a conference and related issue of Daedalus that focused on the social standing and prospects of African Americans. Later, he supported developing a program in African American studies at Harvard. ${ }^{5}$

Parsons' own contribution to the Daedalus issue was the essay "Full Citizenship for the Negro American?" (Parsons 1965). When plans were made to expand the special issue of Daedalus into a full volume, The Negro American, Parsons served as its coeditor with Kenneth Clark, the prominent African American social psychologist. Later, he helped to plan another issue of Daedalus, and associated book, Color and Race, edited by the distinguished African American historian, John Hope Franklin, that dealt with race relations in international perspective. He contributed an interesting, although rapidly written and less systematic, essay, "The Problem of Polarization on the Axis of Color" (Parsons 1968).

The essay "Full Citizenship for the Negro American?" presents Parsons' understanding of the importance of the Civil Rights Movement. He ended the title with a question mark to highlight his understanding that the outcome of the movement was far from certain. Like "Social Strains in America", the essay used sociological analysis to clarify the broad social context in which social and political events important to the entire nation were taking place. Yet, the two essays differed in a key respect. The earlier essay had argued that the McCarthy movement was likely less momentous than many European and American intellectuals feared. "Full Citizenship..." argued that the social change involved in the Civil Rights Movement was leading toward a major reintegration of the society.

Parsons viewed this reintegration as strongly rooted in historical processes that had seen white ethnic groups of diverse origins accepted into a society originally founded by Protestant, predominantly Calvinist, peoples from England, Scotland, and the Northwest of continental Europe. He also saw the reintegration as part of a broad extension of welfare rights that had started after the Civil War, regressed in the late nineteenth century, then revived through the policy innovations of the New Deal. While Parsons recognized that welfare rights were less fully developed in America than in Western and Northern Europe, he believed that the U.S. was uniquely multi-ethnic among modern nations and expected it would become authentically multi-racial. Today, equality among white ethnic groups is notably greater than when Parsons wrote and progress toward multiracial equality of opportunity has been substantial, although uneven and limited by complicated obstacles. Parsons anticipated only to a small degree that progress toward multiracial integration would involve a variety of Latino and Asian ethnic groups as well as African Americans. He was correct in emphasizing that the destiny of African Americans, as the only ethnic group to have entered

\footnotetext{
${ }^{5}$ Near the end of his life, Parsons was approached by Jonathan Mitchell, the younger brother of an Amherst classmate, who wanted to donate a chair in Women's Studies (something that did not then exist) to Harvard in memory of his feminist late wife, Doris Stevens. The Harvard administration balked when Parsons presented Mitchell's proposal with his own approval. After Parsons' death, Mitchell asked Renee Fox and me for help. Our advice ended in the establishment of the Doris Stevens Chair in Women's Studies at Princeton University, which revolves among social science and humanities departments.
} 
American society involuntarily, in slavery, held special significance, and presented special complications for multiracial integration.

The "Full Citizenship..." essay started with the theoretical question of what part civil rights play in the integrative institutions of modern societies. Parsons addressed this question by outlining historical stages in the development of effective institutions of civil rights in Anglo-American history. Following the British scholar, T.H. Marshall (1964), he distinguished three separate complexes of citizenship rights: the legal, involving equal protection of the laws and access to the courts; the political, involving the franchise and the ability to exercise influence in the political process; and the welfare, involving health, education, and welfare policies that enable citizens to participate effectively in modern socio-economic roles. Parsons then reviewed the historical processes by which different religious and ethnic groups had gained comparatively full recognition of their citizenship rights despite earlier exclusion from full membership in the society. Down to the era of mass immigration that started with the arrival of Irish Catholics escaping famine, the U.S. had been overwhelmingly ascetic Protestant, with only small numbers of Catholics, Jews, and even Lutherans. Aside from slaves and the few free Blacks, the society had been overwhelmingly white and Anglo-Saxon. The nation's common culture derived predominantly from the Calvinist sectors of the English, Scottish, and Scotch-Irish populations, with small admixtures of French, German, Dutch, and Swedish populations, also mainly Protestant. The nation's strongly Protestant heritage created long-lasting resistance to acceptance of Catholic populations. It also resulted in widespread orientation to matters of race in terms of religiously grounded symbolism of black and white as representing good and evil. Democratic social integration of diverse ethnic and racial groups since the aftermath of the Civil War had thus faced strong cultural, economic, and political barriers.

From the 1840 s to the 1920 s, Parsons noted, large-scale immigration from Ireland, Central Europe, Scandinavia, Eastern Europe, and Italy made the American population much more diverse. The new ethnic and religious groups, especially Catholics and Jews, were often received with negative feelings and various social restrictions; in many ways, they were excluded from the shared communities of American life. A symbol of exclusion, well known in Boston and Cambridge, had been the note "Irish Need Not Apply" appended to postings of jobs available. As background to his analysis of the status of African Americans, Parsons traced the processes of institutional change that, after many years of discrimination, led to the inclusion in American communities of previously excluded groups, such that they attained statuses of approximate social equality. Parsons hypothesized that the processes of inclusion experienced by other religious and ethnic groups might model the inclusion of African Americans, then unfolding. He noted that full inclusion under the protections of the complex of legal rights, a process advanced by the Supreme Court's Brown vs. Board of Education decision and, pending when Parsons wrote the essay, by the Civil Rights Acts of the mid-1960s, created new abilities for African Americans to press for recognition of additional rights in court. He was optimistic that the establishment of voting rights for African Americans throughout the country would result in favorable political changes, as elected office holders would then need to respond to the political interests of African Americans. Parsons suggested that the most complicated struggle for African Americans would involve full and equal inclusion regarding the welfare dimension of citizenship rights. He believed that African Americans would not achieve complete 
equality as citizens, including full acceptance in informal personal relationships and as members of local communities, until they benefitted from equality in educational opportunities, health care, and welfare support. Today, his predictions appear largely correct, but the struggle for sufficient welfare rights has faced a strength of political opposition he did not anticipate. With Nixon's southern strategy, followed by Reagan's opposition to welfare policies and Trump's appeals to white privilege, political strains have continued to limit progress on racial equality and inclusion.

Parsons attempted to present his views on American race relations before a general audience by writing an article on the Civil Rights Movement for the magazine of The Washington Post. However, he was not able to craft an article that was clear and forceful enough to be accepted by the editors, nor were my efforts at editing sufficiently helpful. Similarly, his manner of public speaking was not suited for speeches to general audiences, even though his lectures, at their best, were clear and effective in academic settings. Thus, his public role on the Civil Rights Movement was limited. Yet, the "Full Citizenship..." essay was widely read among academics and intellectuals during the 1960s. It was appreciated by some influential figures in the Civil Rights Movement and in circles in the federal government where race and welfare rights policies were undergoing change.

In the late 1960s, a principal public issue concerned the War in Vietnam. American involvement began during the Kennedy administration and was greatly expanded under President Johnson and then extended by President Nixon. Parsons' skepticism about the war evolved into clear opposition during the Johnson administration, although he supported many of Johnson's domestic policies, especially on civil rights. Although opposed to the war, Parsons spoke of his views mostly in private, thus differing from Robert Bellah, who gave public lectures against the war at university "teach-ins". However, Parsons participated in a discreet undertaking to affect policy on the war. With a group of several other senior members of the Harvard faculty, he traveled to Washington to meet with Johnson's National Security Advisor, MacGeorge Bundy, the former Harvard Professor of Government and Dean of the Faculty of Arts and Sciences, whom the group regarded as a colleague. Their shared goal was to offer advice on the importance of winding down the war. The group had understood that, if their meeting with Bundy went well, they would be shown into the Oval Office to discuss war policy with President Johnson. Bundy apparently concluded that Johnson would not want to hear the offered advice; the disappointed group was ushered out of the White House. ${ }^{6}$

During the late ' 60 s and early ' $70 \mathrm{~s}$, the turmoil in many of the nation's universities became another public issue that Parsons addressed. The turmoil originated partly as a spillover from student involvement in the Civil Rights Movement, active opposition to the Vietnam War, and the emerging Women's Movement. Students challenged the authority of faculties and administrations, demanding change in academic institutions as they affected student rights and opportunities. Among the major themes of activists were criticism of faculty who allegedly devoted too much time to research and too little to teaching, a demand for curricula shaped less in terms of academic disciplines and more in terms of issues "relevant" to students' interests and future careers, and charges

\footnotetext{
${ }^{6}$ Compare the account in Mark Gould's essay in this issue. My account is based on what Parsons told me about the meeting with Bundy when we next met a couple of days after his return from Washington.
} 
that the universities had been corrupted by ties to government and business corporations. Student demonstrations and occupations of buildings disrupted many universities. In some cases, there were ugly confrontations between students and local police, called in to protect university property. At Harvard, students broke into confidential personnel records of faculty members. ${ }^{7}$ Demonstrations and crises at one university after another created a public perception that academic institutions were in trouble.

At the time, Parsons was collaborating with Gerald M. Platt on an empirical study of faculty roles in institutions of higher learning, with a special focus on research universities (cf. Parsons and Platt 1972). When Parsons was asked to write a report on the crisis by the Assembly on University Goals and Governance, created by the American Academy of Arts and Sciences, he and Platt redirected their work. The resulting book, The American University (Parsons and Platt 1973), provides a comprehensive analysis of the institutional make-up of colleges and universities, focusing on large, multi-school, research universities with central arts and sciences faculties - the type of institution where the student demonstrations had been concentrated.

Parsons and Platt began with an overview of the modern university as an institution specialized around the functions of producing, preserving, and transmitting cognitive culture and intellectually disciplined knowledge. They then addressed the central role of research and the training of graduate students for careers devoted to academic research and teaching. They also discussed the special ways in which undergraduate education, and educational curricula designed for undergraduates, were organized within research universities. In that context, they argued that the intellectual scope and quality of undergraduate education had been greatly strengthened by the growth of resources for diverse and specialized research. They also argued that undergraduate education is a dynamic process in which many students undergo important processes of personal change. The modern university ideally provides a stimulating and yet supportive setting for students to explore new intellectual and personal interests, often in relation to new awareness of future career options. The university environment typically expands the range of experiences for undergraduates, as the curriculum is designed to be broader and more challenging than students have previously encountered. They gain new opportunities to become involved in the arts, in politics and public controversy, and in moral and religious subcultures. Their extracurricular activities, friendships, and even intimate relationships are more likely to involve people of diverse backgrounds.

Parsons and Platt noted that college students often undergo significant stress when, at university, their previous life-orientations are challenged by new experiences. The stress tends to be particularly great for students whose families and friends had not experienced higher education and might not understand their choices of fields of study, extracurricular interests, social and political causes, friendships, and career plans. The rapid expansion of universities after World War II down to the 1970s, which enabled ever larger percentages of age cohorts to obtain higher education, likely increased

\footnotetext{
${ }^{7}$ One supposed revelation was that the economics professor, Arthur Smithies, consulted for the C.I.A. In fact, Smithies, as Master of Kirkland House, enjoyed inviting C.I.A. officials to meet with students in the house and give talks on their work. He introduced a few of them as his "boss" at the C.I.A. and then enjoyed watching them be criticized by students and tutors in the house. I had a long discussion with Richard Bissell, whom Smithies had introduced as the person responsible for planning the Bay of Pigs fiasco.
} 
aggregate student stress. The expansion had also precipitated dislocations in university institutions. With larger student bodies, student-faculty relationships were often less close and personalized. Enlarged academic departments changed relationships among faculty members, often making them more impersonal and competitive. The growth in administrative structures had created difficulties in dealing with students in nonbureaucratic ways, a matter symbolized at the time by academic records kept on 'IBM cards' and with impersonal ID numbers. Processes by which students formed friendships had changed as student bodies became more diverse in social class and regional, ethnic, racial, and cultural backgrounds. The resulting stresses on students had weakened the social integration of university life, another case where rapid institutional change led to dislocation, stress, and crisis.

Parsons and Platt made several recommendations about responding to student demands over the lack of 'relevance' in university curricula, over students' lack of power in university decision-making, and over addressing political issues of the day in research and teaching. They recommended, first, that the system of higher education should not overreact to the turbulence. American society had been experiencing an "educational revolution" with a great expansion in access to higher education and in graduates' qualifications to assume technical occupational roles. Research universities had been the cutting edge of this revolution and needed to be protected if its societal benefits were to be sustained. Yet, some accommodations could be made. The relevance of the curriculum could be increased by expanding the role of the arts in university life and by strengthening the applied sciences and social sciences. Student representation could be added to some university committees to engage student perspectives in decision-making, although it remained important to recognize that faculty members, typically longer-term participants in a university, have larger interests in, and responsibilities to, its well-being than do students. However, considerable stress is inherent to the personal changes that individuals should experience during the lifestage of "studentry". Parsons and Platt warned against making student life more comfortable in emotional terms at sacrifice of the personal challenges that should occur during university-based socialization. They also warned against the intrusion of changes in the institutional make-up of universities when animated by external political considerations, as had occurred at the University of California under Governor Ronald Reagan. They warned that internal politicization of universities in response to the student left risked further intrusions in university affairs from the political right. They perceived the sensitivity on the right toward open-ended discussion of social and political issues in the universities, where traditional beliefs and values were often questioned. While they firmly defended freedom of discussion, they noted that reaction from the right could damage academic freedoms as well as reducing commitment of public resources to the universities.

The American University had less political and intellectual effect than Parsons had hoped. Given the complexity of its analysis, the book had taken a few years for its arguments to be formulated and its text to be written. During that time, the national sense of crisis over the universities had waned. The complexity of the book's analytical argument hindered readers not familiar with the theory of action in grasping its import. The study gained relatively little attention in public policy circles, even in academic policy circles. It has been regarded more widely as a creative but overly intense theoretical exercise, rarely as a source of wisdom on university policy. 


\section{Conclusion}

This essay has reviewed Talcott Parsons' commitments to a methodology based in part on the Weberian concepts of the value-freedom of intellectual disciplines, the standards of objectivity that protect scholarly value-freedom, and the value-relevance, often political in nature, of contributions to knowledge, always created in terms of historically conditioned purposes and potentialities. Following these methodological principles, Parsons made several significant attempts to apply sociological analysis to issues of public policy. Some of the most notable efforts made positive contributions to public discussion: his anti-Nazi writings and broadcasts, his opposition to the Morgenthau plan, his essay on aggression in the Western world, his essay on McCarthyism and the sources of its political support, his essays, though less well known, proposing moderation of Cold War policies, and his essays supporting the Civil Rights Movement. The effort to use confidential channels of influence into the White House to change policy on the Vietnam War failed. Publication of The American University produced limited effect on public discussion, due to the book's timing and its analytical complexity. All of Parsons' attempts to influence public discussion of policies were made from a stance of broadly liberal values with special emphasis on principles of free speech, free association, and freedom of teaching, research, and publication. All the attempts were also made as applications of sociological analysis and, more specifically, Parsons' developing theory of social action. As made clear in his essay, Social Science; A Basic National Resource (Parsons 1948, 1986), Parsons also believed that the social sciences, as developing intellectual disciplines, held promise of substantial value-relevance as means of guiding practical improvements in public policy and social life.

The materials reviewed above contrast profoundly with Parsons' reputation that he was personally conservative, that his focus on social order left no room for a theory of social change, and that, therefore, his theory was rigidly conservative. The belief that Parsons disattended social change may derive in part from readings of the chapter on social change in The Social System. There Parsons set forth the ideal of a set of propositions explaining change that would have a logical status somewhat similar to Newton's laws of motion. Parsons acknowledged that neither he nor other sociologists were approaching such a model and, in that sense, lacked a theory of social change. The argument that he lacked a theory of change and was thus necessarily conservative may also derive from the multifactorial, Weberian mold of his writings on social change, from The Structure of Social Action to the applied essays discussed above, to Societies; Evolutionary and Comparative Perspectives, and The System of Modern Societies. His analyses of change did not focus on a succession of discrete, social class dominated stages in the manner of Marxian or neo-Marxian theories. If the belief is that, unless he adopted a theory of succession of class-dominated historical stages and looked forward to a stage of working-class control, he must have been conservative, it would follow that he and his writings were conservative. However, that special understanding contradicts conventional uses of the terms liberal and conservative in American and European public discourse. Our conclusion is that Parsons sought in his writings, where they addressed practical social and political issues, to advance a value-relevance of liberal thought and action. 


\section{Declaration}

Conflict of Interest The author has no conflict of interest with respect to this essay or any of the materials included within it.

Open Access This article is licensed under a Creative Commons Attribution 4.0 International License, which permits use, sharing, adaptation, distribution and reproduction in any medium or format, as long as you give appropriate credit to the original author(s) and the source, provide a link to the Creative Commons licence, and indicate if changes were made. The images or other third party material in this article are included in the article's Creative Commons licence, unless indicated otherwise in a credit line to the material. If material is not included in the article's Creative Commons licence and your intended use is not permitted by statutory regulation or exceeds the permitted use, you will need to obtain permission directly from the copyright holder. To view a copy of this licence, visit http://creativecommons.org/licenses/by/4.0/.

\section{References}

Bellah, R. N. (1975). The broken covenant; American civil religion in a time of trial. New York: Seabury Press.

Bortolini, M. (forthcoming) Biography of Robert N. Bellah.

Fararo, T. J. (1976). On the foundations of the theory of action in whitehead and Parsons. In J. J. Loubser, R. C. Baum, A. Effrat, \& V. Lidz (Eds.), Explorations in general theory in social Science, vol. 1. New York: Free Press.

Fox, R, C. (1997) “Talcott Parsons, my teacher”. American scholar, 66 (395-410. Reprinted in victor Lidz, editor (2011) Talcott Parsons (Farnham, Surrey, Ashgate).

Frankfort, H. (1948). Kingship and the Gods. Chicago: University of Chicago Press.

Gerhardt, U. (1993). Talcott Parsons and national socialism. New York: Aldine De Gruyter.

Gerhardt, U. (2002). Talcott Parsons; an intellectual biography. Cambridge: University of Cambridge Press.

Henderson, L. J. (1932). “An Approximate Definition of Fact”, reprinted in Bernard Barber, editor (1970) L. $J$. Henderson on the social system. Chicago: University of Chicago Press.

Loubser, J. J. (1976). General introduction. In J. J. Loubser, R. C. Baum, A. Effrat, \& V. Lidz (Eds.), Explorations in General Theory in Social Science, vol. 1. New York: Free Press.

Mannheim, K. (1929/1936). Ideology and utopia. New York: Harvest Books.

Marshall, T. H. (1964). Class, citizenship, and social development. Garden City, NY: Doubleday and Company.

Nielsen, J. (unpublished) Parsons Life-Data.

Parsons, T. (1927/2019a). Kapitalismus bei Max Weber - zur Rekonstruktion eines fast vergessenen Themas, edited by Uta Gerhardt. Wiesbaden: Springer.

Parsons, T. (1927/2019b). Der Kapitalismus bei Sombart and Weber/Capitalism according to Sombart and Weber, edited by Guenter Stumvoll and Bruce C. Wearne. Vienna and Zurich: Lit Verlag.

Talcott Parsons (1928) "Capitalism in Recent German Literature: Sombart and Weber, 1". Journal of Political Economy, 36 (641-661). Reprinted in Charles Camic, editor (1991) Talcott Parsons; the early essays (Chicago: University of Chicago Press).

Parsons, T. (1929). “Capitalism in Recent German Literature: Sombart and Weber, 2.” Journal of Political Economy, 37 (31-51). Reprinted in Charles Camic, editor (1991) Talcott Parsons; the early essays. Chicago: University of Chicago Press.

Parsons, T. (1936). "Review of Alexander von Schelting, Max Weber's Wissenschaftslehre”. American Sociological Review, 1 (675-681). Reprinted in Charles Camic, editor (1991) Talcott Parsons; the early essays. Chicago: University of Chicago Press.

Parsons, T. (1937). The structure of social action. New York: McGraw-Hill.

Parsons, T. (1940) "New Dark Ages Seen if Nazis Should Win". Boston Evening Transcript, September 28, 1940. Reprinted in Gerhardt, Talcott Parsons and National Socialism.

Parsons, T. (1942a). Max Weber and the Contemporary Political Crisis. Review of Politics, 4, 61-76-155-172 Reprinted in Gerhardt, Talcott Parsons and National Socialism. 
Parsons, T. (1942b). Democracy and the Social Structure of Pre-Nazi Germany. Journal of Legal and Political Sociology, 1, 96-114 Reprinted in Gerhardt, Talcott Parsons and National Socialism.

Parsons, T. (1942c). Some Sociological Aspects of Fascist Movements. Social Forces, 21: 2, 138-147 Reprinted in Gerhardt, Talcott Parsons and National Socialism.

Parsons, T. (1946). "Certain primary sources and patterns of aggression in the social structure of the Western world”. Psychiatry, 10 (167-181). Reprinted in Parsons (1954) Essays in Sociological Theory. New York: Free Press.

Parsons, T. (1948). Social Science; A Basic National Resource. In S. Z. Klausner \& V. Lidz (Eds.), (1986) The nationalization of the social sciences. Philadelphia: University of Pennsylvania Press.

Parsons, T. (1951). The social system. New York: Free Press.

Parsons, T. (1955) "McCarthyism and American social tension; a Sociologist's view". Yale Review, 226-245. Reprinted as "social strains in America" in Daniel Bell, editor, The new American right (New York: Criterion Books).

Parsons, T. (1959). “An approach to the sociology of knowledge”. Proceedings of the Fourth World Congress of Sociology, 4 (25-49). Reprinted in Talcott Parsons (1967) Sociological Theory and Modern Society. New York: Free Press

Parsons, T. (1960). Structure and process in modern societies. New York: Free Press.

Parsons, T. (1961a). The Problem of International Community. In J. Rosenau (Ed.), International Politics and Foreign Policy. New York: Free Press.

Parsons, T. (1961b). Polarization of the world and international order. In Q. Wright, W. M. Evan, \& M. Deutsch (Eds.), Preventing world war III. New York: Simon \& Schuster.

Parsons, T. (1963a) 'On the concept of political power'. In Talcott Parsons (1969) Politics and Social Structure New York: Free Press.

Parsons, T. (1963b). "On the concept of influence”. In Talcott Parsons (1969) Politics and Social Structure. New York: Free Press.

Parsons, T. (1965). "Full Citizenship for the Negro American?” Daedalus (November). Reprinted in Talcott Parsons and Kenneth Clark, editors, (1966) The negro American. Boston: Houghton Mifflin.

Parsons, T. (1966) Societies: Evolutionary and Comparative Perspectives (Englewood cliffs, NJ: PrenticeHall.

Parsons, T. (1968) "The problem of polarization on the Axis of color". John Hope Franklin, editor, Color and Race Boston: Houghton Mifflin.

Parsons, T. (1969) "On the concept of value-commitments". In Talcott Parsons (1969) Politics and Social Structure New York: Free Press.

Parsons, T. (1970) "Some problems of general theory in sociology". John C. McKinney and Edward a. Tiryakian, editors, Theoretical Sociology: Perspectives and Developments New York: Appleton-CenturyCrofts.

Parsons, T. (1971). The system of modern societies. Englewood Cliffs, NJ: Prentice-Hall.

Parsons, T. (1977/2006). The sociology of knowledge and the history of ideas. In H. Staubmann (Ed.), Action theory; Methodological Studies. Wien: Lit Verlag.

Parsons, T. (1978). A paradigm of the human condition. In Action theory and the human condition. New York: Free Press.

Parsons, C. (2004) "Some remarks on Talcott Parsons's family". The American Sociologist, 35 (4-22). Reprinted in victor Lidz, editor (2011) Talcott Parsons (Farnham, Surrey, Ashgate).

Parsons, T., \& Cutler, A. T. (1923). A word from Amherst students. The New Student, 20(1923), 6-7.

Parsons, T., \& Platt, G. M. (1972). Higher education, changing socialization, and contemporary student dissent. In M. W. Riley, M. E. Johnson, \& A. Foner (Eds.), Ageing and Society, vol. 3; A Sociology of Age Stratification. New York: Russell Sage.

Parsons, T., \& Platt, G. M. (1973). The American University (Cambridge: Harvard University press).Talcott Parsons (1978) "a paradigm of the human condition". In Talcott Parsons (1978) Action Theory and the Human Condition. New York: Free Press.

Radkau, J. (2009). Max Weber; a biography. Cambridge: Polity Press.

Schrecker, E. (1986). No ivory tower: McCarthyism and the universities. New York: Oxford University Press.

Schwanenberg, E. (1976). On the Meaning of the Theory of Action. In J. J. Loubser, R. C. Baum, A. Effrat, \& V. Lidz (Eds.), Explorations in General Theory in Social Science, vol. 1. New York: Free Press.

Stouffer, S. A. (1955). Communism, conformity, and civil liberties. Garden City: Doubleday.

Stouffer, S. A., \& others. (1949). Studies in social psychology in world war two: The American soldier. Princeton: Princeton University Press.

Weber, M. (1919a). Politics as a Vocation. In H. H. Gerth \& C. W. Mills (Eds.), From Max Weber; Essays in Sociology. New York: Oxford University Press, 1946. 
Weber, M. (1919b). Science as a Vocation. In H. H. Gerth \& C. W. Mills (Eds.), From Max Weber; Essays in Sociology. New York: Oxford University Press, 1946.

Weber, M. (1920a). The Protestant Ethic and the Spirit of Capitalism in Gesammelte Aufsaetse zur Religionssoziologie. Tuebingen: Siebeck; first published in 1903-04.

Weber, M. (1920c/1952). Ancient Judaism. New York: Free Press.

Weber, M. (1920d/1958). The religion of India. New York: Free Press.

Weber, M. (1922/1968). Economy and society. New York: Bedminster Press.

Weber, M. (1926/1975). Max Weber; a biography. New York: Wiley.

Weber, M. (1949) The Methodology of the Social Sciences (New York Free Press).

Wenzel, H. (1990). Die Ordnung des Handelns; Talcott Parsons' Theorie des allgemeinen Handlungssystems. Frankfurt: Suhrkamp.

White, W. (1961). Beyond conformity. New York: Free Press.

Whitehead, A, N. (1925) Science and the Modern World (New York Macmillan).

Publisher's Note Springer Nature remains neutral with regard to jurisdictional claims in published maps and institutional affiliations. 